\title{
Project management in emergency situations at the level of local self-governments in case of floods
}

\author{
Goran Radovanović \\ Rectorate \\ University of Defence in Belgrade \\ Belgrade, Serbia \\ goranradovanovicbg@gmail.com
}

\author{
Samed Karović \\ Faculty of Security Studies \\ University EDUCONS in Sremska \\ Kamenica \\ Sremska Kamenica, Serbia \\ samed.karovic@educons.edu.rs
}

\author{
Miroslav Bjegović \\ Faculty of Security Studies \\ University EDUCONS in Sremska \\ Kamenica, \\ Sremska Kamenica, Serbia \\ bjegovicj.miroslav@gmail.com
}

\begin{abstract}
The paper explains the theoretical concept of emergencies, the importance and role of local selfgovernments in such situations. The current state of affairs in local self-governments in the domain of organization of local self-government for possible reaction to emergencies is analyzed, and the significance of the project approach in the development of Emergency Protection and Rescue Plans is underlined.
\end{abstract}

Keywords-project management, emergency situations, local self-government, protection and rescue plan.

\section{INTRODUCTION}

An increasing number of emergency situations of varying character has a negative impact on the socioeconomic development of the state, its security and the security of the population. The essence of work and the presentation of the results is directly related to the creation of the conditions of peoples' security and their normal life, society, state and other socioeconomic structures that face various natural risks from emergency situations caused by floods. Such a concept can be achieved through various prevention measures and appropriate Protection and Rescue Plans in Emergency Situations.

The project approach to designing protection and rescue plans in emergency situations at the level of local self-government provides a framework for response in various events that may lead to the proclamation of an emergency situation.

Local self-government represents a key segment of action in the case of emergency situations of any kind and is the basis for successful protection and rescue in such situations. In this case, the project is based on the emergency situation declared as a result of floods.

\section{THEORETICAL CONCEPT OF EMERGENCY SITUATION}

The natural disasters in recent years, with the consequences they cause, significantly jeopardize the social community, human lives, material goods and the environment. The actuality of emergency situations induces the constant need of the community to find an adequate response to the security threats [1].
Modern times have led to the more complex causes for the proclamation of emergency situations, they are more devastating and, owing to the informationcommunication technologies, are increasingly present in public as well as in everyday life. Scientific and expert bodies and institutions dealing with emergency situations have defined or have created many mechanisms that can be foreseen, prevent, counteract and reduce the consequences of emergency events [2].

As the authors of S. Karović and G. Radic "The problem of a clear theoretical definition and understanding of the term emergency situation today, when each state faces a number of risks and dangers, is another problem that makes it difficult for the successful and efficient functioning of all entities in the protection and rescue of people, material goods and the environment. More frequent and devastating accidents, accidents, disasters, natural disasters and other forms of endangering the population and society as a whole imposes the need to clearly define and clarify the legal instrument for which the state intervenes in situations where the basic conditions for life and work are endangered" [3].

Article 2, paragraph 7 of the Law on Reduction of Risks and Disasters and Emergency Management defines the meaning of the term "emergency situation", which implies "a situation arising from a proclamation by a responsible authority when the risks and threats or consequences for the population, environment and material and cultural goods of such scale and intensity that their occurrence or consequences cannot be prevented or eliminated by the regular operation of responsible authorities and services, which makes it necessary to use special measures, strengths and means with enhanced operating regime for their mitigation and removal" [4].

The legal regulation itself does not see the essence of the risks of a different nature with possible significant consequences. This primarily refers to cumulative and anecdotal, anthropogenic, technical and natural risks, whereby an emergency situation is practically caused by the lack of resources for the protection of risk facilities (people, social groups, material resources, technical systems and facilities, ecological systems), becoming harmful [5]. It can be concluded that the essence of the emergency situation 
is in violating the functioning of normal living conditions and the work of people, jeopardizing their health and damaging the property and economy of the country as a whole.

An emergency situation is characterized as unplanned. It violates normal life and work of people and makes material and financial damage. Also, it engages capacities from the wider territory of the state in order to sanitize and mitigate the damage. When it comes to the classification of emergency situations, the practical applicability has the criterion of the cause of an emergency situation [5]. According to this criterion, emergency situations are classified as:

- Emergency situations of technogenic character;

- Emergency situations of natural character and

- Emergency situations of anthropogenic character.

Emergency technogenic situations include: transport disasters (catastrophes); fires; explosions; accidents with ejection (danger of eviction) of strong toxic substances; disasters with eviction (risk of eviction) of radioactive substances; disasters with eviction (risk of eviction) of biologically hazardous substances; sudden demolition of buildings; damage to electrical energy systems; damage to utility supply systems; damage to purification plants and hydrodynamic devastation [5].

Especially characterizing are emergency situations of natural character which include: geophysical phenomena (earthquakes, volcanic eruptions); geological phenomena (landslides, torrents, slopes, avalanches, slopes, abrasion, erosion); meteorological and agrometeorological phenomena (hurricane, storm winds, heavy rain, large snow, heat, drought); marine hydrological phenomena (tropical cyclones-typhoons, tsunamis, high waves, strong thrust in ports, ice pressure); hydrological phenomena (floods, rainfalls, lower water levels, early freezing and ice occurrence on navigable rivers and reservoirs, increase of groundwater level); natural fires (forest fires, peat fires, underground combustible fires); infectious diseases of people (group cases of dangerous infectious diseases, epidemics, pandemics, infectious diseases of unknown etiology); infectious diseases of domestic animals (individual cases of exotic and extremely dangerous infectious diseases, enzootics, epizootics, panzotia, infectious diseases of domestic animals of unmet etiology); destruction of agricultural plants with diseases and pests (progressive epiphytotyping, panfitoty, disease of agricultural plants of undiagnosed etiology, mass spread of plant pests) [5].

When it comes to emergency situations of anthropogenic character, it is primarily thought of: emergency situations related to the change of the state of the land (catastrophic shuffling, slipping, surface rupture due to the inland movement of the earth when digging ore and other human activities, exhaustion of non-renewable natural resources, over pollution); emergency situations associated with changing the composition and properties of the atmosphere (change of weather or climate as a result of anthropogenic activity, temperature inversion over cities, atmospheric pollution, ozone depletion, significant change in the airiness of the atmosphere); emergency situations related to the change in the state of the hydrosphere (lack of drinking water due to water exhaustion or pollution, lack of water resources necessary for organizing day-to-day economic water supply and securing technological processes, disturbance of economic activity and ecological balance due to pollution of the seas and the oceans); emergency situations related to the change of biosphere status (extinction of species, destruction of plants on wider territory, changes in the biosphere's ability to reproduce renewable resources, mass destruction of animals); socio-political conflicts (wars, terrorist attacks, international, interethnic and religious conflicts) [5].

It should be noted in particular that emergency situations caused by natural disasters or human activities violate many human lives on a daily basis and in various ways they destroy and degrades the environment, causing great material damage and losses.

\section{NATURAL DISASTERS}

Natural disasters are the result of various natural processes. Natural processes shape natural conditions that include a complex of elements of the natural environment, including relief, background, climate, water, a type of vegetation, and a man that determines different aspects of the use of a given space. The basic characteristic of natural conditions is that they can to a certain extent, be changed and adjusted to human needs.

Natural disasters are seemingly inevitable, mostly unexpected occurrences. If they do great harm to society or its parts, they become disasters. Elementary disasters are different by cause, but similar in consequence [6].

\section{A. Concept and basic characteristics of elemental disasters}

In the meaning of the term "natural disaster", according to the Act on Disaster Risk Reduction and Emergency Management [4], Article2, paragraph 2 states that "natural disasters are the occurrence of hydrological, meteorological, geological or biological origin caused by the action of natural forces such as earthquakes, floods, torrential rains, storms, heavy rain, atmospheric discharges, city, drought, or landslides, snow layers and avalanches, extreme air temperatures, the accumulation of ice on the watercourse, the pandemic, the epidemic of infectious diseases, the epidemic of livestock contagious diseases and the occurrence of pests and other natural occurrences of larger proportions that can endanger the safety, life and health of a large number of people, material and cultural goods or the environment on a larger scale". 
In accordance with the above, the events listed include emergency situations previously classified according to established criteria in theoretical consideration of emergencies.

According to the National Strategy for Emergency Response and Rescue (hereinafter: the Strategy) every decade it were: 100 natural disasters in the period $1900-1940$; 650 natural disasters in the period 19601970; 2000 natural disasters in the period 1980-1990; while in the ten-year period 1990-2000 the number of disasters has increased to 2800 . The trend shows that the number of emergencies and dangerous situations increases permanently, and in recent years economic costs have tripled [7]. The above indicators sufficiently show about the damage in the economy of the state and losses in the field of material goods, but also those atmospheric phenomena also lead to the loss of human lives.

Also, the Strategy emphasized "...the origin, extent and duration of natural disasters in most cases cannot be predicted in advance, but for certain phenomena, based on experience, statistical data and modelling methods, according to the location of the phenomenon, it can be assumed that will occur" [7].

Regarding the above mentioned, an assessment of the vulnerability of the territory of the Republic of Serbia from floods and slopes of the terrain was made. Also, on the basis of available statistical data, a map of risks from natural disasters was made (forest fires, floods, landslides and earthquakes).

\section{B. Floods}

Old threats, such as floods, also reveal a certain "vulnerability" of a society that is not prepared to respond at any given moment to such a kind of challenge. In this sense, timely response to such situations is of particular importance because the consequences of natural disasters, especially floods, are limited and reduced.

As pointed out by Mlađan D. "Flood is considered the overflow of large waters from natural and artificial river beds and water reservoirs. As a kind of category of natural processes or phenomena of atmospheric or hydrological nature, floods can last long, affect a large area with great consequences for people, created values, environment and agricultural land. According to the EM-DAT (Emergency Events Database), in the period from 1900 to 2010. years were over 3. 000 catastrophic floods, with more than 200.000 victims and impacts on about three billion people. Currently, in the world, 800 million people live in areas exposed to floods, and 70 million are exposed to flooding each year" [8].

The same author states that "total length of the watercourse in the territory of Serbia is $65.980 \mathrm{~km}$, and the density of the river network is 0.75 $\mathrm{km}^{2}$. Potential water areas for a return period of 100 years cover an area of $16.000 \mathrm{~km}^{2} ; 500$ large settlements, 515 industrial facilities, $680 \mathrm{~km}$ of railroads, and about $4000 \mathrm{~km}$ of roads are endangered. The most vulnerable area in the northern part of Serbia (Vojvodina), wherein the coastal part of the Danube (Tisa, Tamiš and Sava) there is around $12.900 \mathrm{~km}$ of land potentially susceptible to floods" [8].

Based on the aforementioned features of natural disasters and floods as one of the key elements, one can ascertain the importance of finding solutions and the existence of operational protection and rescue plans in such situations. Plans should reflect the reality of flood risk assessment and real implementation in preventive and operational tasks in situations of protection and rescue of population and material goods.

\section{ANALYSIS OF THE ACTUAL SITUATION IN LOCAL SELF-GOVERNMENT}

In order to examine the state of preparedness of local self-governments in the emergency situations caused by floods in the area of AP Vojvodina, it was necessary to design an instrument for recording such a state. The instrument was designed in the form of a checklist, and it covered the key issues that reflected the state of preparedness of local self-government in emergency situations caused by floods.

The current situation is based on key issues that include: the vulnerability of local self-government to floods; legally defined activities related to local selfgovernment affairs in case of flooding; risk assessment; organization of local self-government bodies in case of floods; organization of civil protection; Plan of protection and rescue in emergency situations; integration of the Plan of saving and rescue and analysis of its functioning.

For the purposes of this paper, the elements related to the vulnerability of the local self-government area to floods and the organization of local self-government bodies in the event of floods ae analysed. The local reference self-governments covered by the recording are Sečanj Odžaci, Pančevo, Beočin, Sremska Mitrovica, Bečej, Apatin and Bačka Palanka, which represents $18 \%$ of the total number of local selfgovernments in the area of AP Vojvodina.

\section{Influence of local self-government areas with floods}

From the point of view of the vulnerability of the aforementioned local floods to the floods, the question included 35 indicators of vulnerability shown in Table 1.

It is characteristic that the conditions in local selfconcepts are quite similar and that there are no significant differences. It can be especially noted that local governments, which are taken as a sample, are endangered by floods and that floods occur due to heavy rain and groundwater, and that underground waters cause the greatest damage. Floods occur cyclically at intervals over 10 years, most often during the months of May and October, but that is not the rule. They can also appear in other months during the year. 
It should be emphasized that the damage caused by floods in local self-governments most often threaten agricultural land. But, in some conditions, the urban environments also are not protected. It should be emphasized when it comes to preventive measures within the local authorities, especially in relation to the prevention of floods, a sewerage network has not been built on a sufficient level. Also, the embankments are not of sufficient length or height and are not always in function to prevent flooding.

TABLE I. VULNERABILITY OF LOCAL SELF-GOVERNMENT AREAS OF FLOODS

\begin{tabular}{|c|c|c|c|}
\hline \multirow{2}{*}{ No } & \multirow{2}{*}{ Indicators } & \multicolumn{2}{|c|}{ Condition } \\
\hline & & YES & NO \\
\hline 1. & $\begin{array}{l}\text { The floods threaten areas of local self- } \\
\text { government }\end{array}$ & 6 & 2 \\
\hline 2. & Floods occur in the period of 3-4 years & 1 & 7 \\
\hline 3. & Floods occur in the interval of $4-6$ years & 3 & 5 \\
\hline 4. & There is a database of damage caused by floods & 6 & 2 \\
\hline 5. & $\begin{array}{l}\text { Floods occur most frequently during the year in } \\
\text { the months of May and October }\end{array}$ & 7 & 1 \\
\hline 6. & $\begin{array}{l}\text { Floods are characteristic in other months of the } \\
\text { year - there are no rules }\end{array}$ & 3 & 5 \\
\hline 7. & $\begin{array}{l}\text { The most commonly affected are agricultural } \\
\text { areas }\end{array}$ & 5 & 3 \\
\hline 8. & The most damage is on agricultural land & 5 & 3 \\
\hline 9. & The urban areas are not spared & 8 & 0 \\
\hline 10. & $\begin{array}{l}\text { The greatest damage is caused by underground } \\
\text { waters }\end{array}$ & 6 & 2 \\
\hline 11. & Water drainage channels are often neglected & 5 & 3 \\
\hline 12. & The water drain network is not sufficient & 5 & 3 \\
\hline 13. & $\begin{array}{l}\text { Floods occur exclusively due to the elevated } \\
\text { water level in the rivers }\end{array}$ & 4 & 4 \\
\hline 14. & Floods also occur due to heavy rains & 8 & 0 \\
\hline 15. & There are embankments & 2 & 6 \\
\hline 16. & The embankments are not long enough & 2 & 6 \\
\hline 17. & Embankments are not high enough & 3 & 5 \\
\hline 18. & Embankments are irregularly maintained & 5 & 3 \\
\hline 19. & $\begin{array}{l}\text { There is illegal construction in the area of water } \\
\text { streams with a risk of floods }\end{array}$ & 5 & 3 \\
\hline 20. & Channels are irregularly maintained & 8 & 0 \\
\hline 21. & $\begin{array}{l}\text { There are not enough financial resources to } \\
\text { maintain the channel }\end{array}$ & 8 & 0 \\
\hline 22. & $\begin{array}{l}\text { There is not enough awareness of the population } \\
\text { about the needs of prevention and maintenance of } \\
\text { the canals and embankments }\end{array}$ & 7 & 1 \\
\hline 23. & $\begin{array}{l}\text { There is a monitoring system at the level of local } \\
\text { self-government as a form of prevention of the } \\
\text { occurrence of floods }\end{array}$ & 6 & 2 \\
\hline 24. & Floods threaten the lives of the population & 6 & 2 \\
\hline 25. & Floods threaten the health of the population & 6 & 2 \\
\hline 26. & $\begin{array}{l}\text { Floods only affect the properties (houses, houses, } \\
\text { secondary facilities, domestic animals) }\end{array}$ & 5 & 3 \\
\hline 27. & Floods threaten road infrastructure & 7 & 1 \\
\hline 28. & Floods threaten rail infrastructure & 3 & 5 \\
\hline 29. & $\begin{array}{l}\text { Infrastructure for water supply and sewerage, as } \\
\text { well as drinking water springs, has been } \\
\text { endangered by floods }\end{array}$ & 7 & 1 \\
\hline 30. & $\begin{array}{l}\text { Infrastructure for supplying electricity and } \\
\text { telecommunications has been endangered by } \\
\text { floods }\end{array}$ & 4 & 4 \\
\hline 31. & There is a population warning system for floods & 8 & 0 \\
\hline 32. & $\begin{array}{l}\text { There are cooperation and exchange of } \\
\text { information with neighbouring countries }\end{array}$ & 4 & 4 \\
\hline 33. & The time of flooding lasts 1 to 2 days & 4 & 4 \\
\hline 34. & The time of flooding lasts for 3 to 7 days & 1 & 7 \\
\hline 35. & $\begin{array}{l}\text { The duration of flooding lasts for more than } 7 \\
\text { days }\end{array}$ & 5 & 3 \\
\hline
\end{tabular}

It is characteristic for channels and embankments, from the point of view of local self-governments, that they are inconveniently maintained and that there are insufficient financial resources for their regular maintenance. Also, it should be emphasized, and seen from the point of view of local self-governments, that there is not enough awareness of the population about the needs of action for prevention of floods, in particular, the preservation of sewerage network and embankment.

Floods that occur in local self-governments in the AP Vojvodina region endanger the life and health of the population, property, road and rail transport, infrastructure for water supply and sewage, electricity and telecommunication system.

Although according to the recorded state of affairs in the local self-governments, there is a flood monitoring system, it is not at such a level that it can at any moment provide relevant information regarding the state of the floods and possible timely measures. This is the weakness of such organized monitoring of the upcoming dangers of possible floods.

Based on the recorded situation in local selfgovernments, it can also be noted that the floods last more than 7 days and that cooperation with the neighbouring countries exists through the responsible authorities of the Republic of Serbia, but that the local self-government is excluded from this issues.

In the concrete case, it can be noted on the basis of the recorded situation, that local self-governments are endangered by floods that cause heavy rains and underground waters. The constructed sewage network is not sufficient to receive large quantities of water at any moment.Irregular maintenance of the sewerage network has an influence on it as well as the lack of financial resources. Also, the population has insufficient level of awareness for necessity of actions on flood prevention. As the floods happened rarely, the mentioned segment is neglected. It should be noted in particular that in the area of potential flooding water streams, the construction of facilities is also being done - Itendangerboth of natural floods and damage to the ecological system.

\section{Organization of local self-government bodies}

The organization and functioning of local selfgovernment bodies in AP Vovodinain case of emergency situations caused by floods, based on the recorded situation on the representative sample, is shown in Table 2.

TABLE II. ORGANIZATION OF THE LOCAL SELF-GOVERNMENT AUTHORITY

\begin{tabular}{|c|l|c|c|}
\hline \multirow{2}{*}{ No } & \multicolumn{1}{|c|}{ Indicators } & \multicolumn{2}{c|}{ Condition } \\
\cline { 3 - 4 } & & YES & NO \\
\hline 1. & $\begin{array}{l}\text { The timing of the reaction of local self- } \\
\text { government bodies is adequate for the event }\end{array}$ & 7 & 1 \\
\hline 2. & $\begin{array}{l}\text { The system of protection and rescue at the level } \\
\text { of local self-government is integrated into the } \\
\text { system at the level of the Autonomous Province }\end{array}$ & 3 & 5 \\
\hline 3. & System integration is comprehensive & 3 & 5 \\
\hline 4. & $\begin{array}{l}\text { Funds for the functioning of local self- } \\
\text { government bodies for work in emergency } \\
\text { situations caused by floods are sufficient }\end{array}$ & 2 & 6 \\
\hline
\end{tabular}




\begin{tabular}{|c|l|c|c|}
\hline 5. & $\begin{array}{l}\text { Civilian Protection Units at the Local } \\
\text { Government Level are organized for response in } \\
\text { emergency situations in case of floods }\end{array}$ & 5 & 3 \\
\hline 6. & $\begin{array}{l}\text { At the level of local self-government, there is an } \\
\text { organized staff for emergency situations in case } \\
\text { of floods }\end{array}$ & 7 & 1 \\
\hline 7. & $\begin{array}{l}\text { There is a Plan for verifying the functioning of } \\
\text { local self-government bodies in the event of } \\
\text { emergency situations }\end{array}$ & 4 & 4 \\
\hline 8. & $\begin{array}{l}\text { There is a responsibility for monitoring the } \\
\text { situation, issuing tasks to the forces involved in } \\
\text { the elimination of consequences in emergency } \\
\text { situations caused by foods }\end{array}$ & 7 & 1 \\
\hline 9. & $\begin{array}{l}\text { At the level of local self-government, there is a } \\
\text { Plan of protection and rescue in case of floods }\end{array}$ & 6 & 2 \\
\hline 10. & $\begin{array}{l}\text { There are harmonized procedures for requesting } \\
\text { assistance from the authorities of the Ministry of } \\
\text { Internal Affairs and other ministries in case of } \\
\text { emergency situations. }\end{array}$ & 6 & 2 \\
\hline 11. & $\begin{array}{l}\text { During the year, two times a year there is } \\
\text { assessment and harmonization of emergency } \\
\text { response plans for floods }\end{array}$ & 4 & 4 \\
\hline 12. & $\begin{array}{l}\text { The local self-government budget includes } \\
\text { funds for this purpose }\end{array}$ & 7 & 1 \\
\hline 13. & $\begin{array}{l}\text { The funds allocated for training and assessments } \\
\text { are sufficient for the local self-government } \\
\text { bodies to function successfully in conditions of } \\
\text { emergency situations caused by floods }\end{array}$ & 1 & 7 \\
\hline 14. & $\begin{array}{l}\text { There is an annual analysis of the functioning of } \\
\text { local self-government bodies in the event of } \\
\text { emergency situations }\end{array}$ & 5 & 3 \\
\hline 15. & $\begin{array}{l}\text { Funds received in the form of donations after } \\
\text { previous floods are used adequately }\end{array}$ & $\begin{array}{l}\text { Local self-government within the established } \\
\text { Emergency Staffs has persons / teams } \\
\text { responsible for the local economy }\end{array}$ & 8 \\
\hline
\end{tabular}

"There were no donations in three local self-governments

It can be noted that the characteristic elements are primarily manifested in the segments related to the reaction of local self-government bodies in emergency situations, the existence and functioning of the Emergency Situations Staffs caused by floods and the harmonized procedure for requesting assistance from competent instances at the level of the District and the Autonomous Province.

Particularly to be noted, Art. 41 of the Law, "emergency disaster management staff, are established to monitor disaster risk reduction and emergency coordination and management, at the level of local self-government, i.e.for the territory of the municipality - municipal emergency staffs established by the competent municipal authority.

The Emergency Staff creates expert-operational teams as its auxiliary expert bodies.

The Emergency Staffs brings orders, conclusions and recommendations.

The Emergency Staffs has its own seal and office, in accordance with a special law" [4].

Considering the situation in the local selfgovernments related to the organization of local selfgovernment in emergency situations, it is not possible to speak with high reliability about the level of organization, primarily if one takes into account that many issues are not effectively solved. There are partially plans for checking the functioning of local self-government in emergency situations, but this should also be taken with reserve, while the joint assessment that the funds allocated are insufficient to allow the local self-government authorities to function successfully under the conditions of emergency situations caused by floods.

There are no clearly defined elements to assess the organization of local self-government in emergency situations caused by floods. There is no defined procedure for annual analysis of work in such situations, which makes difficult to review of such a situation.

Based on the above mentioned, it can be noted that the level of organization of local self-government in the event of a state of emergency caused by floods does not entail great trust, especially in the segments related to problems of financial and especially professional nature. This can also be concluded on the basis of the statements of respondents served in local self-governments on issues that were not covered by the mentioned indicators. Basically, the key problem is the quality of personnel, lack of financial resources, unrealistic planning and insufficient commitment to the problem of flooding. The reason for this insufficient commitment is the occasional occurrence of floods

\section{PRoJeCt MANAgEMENT In EMERGENCY SITUATIONS AT THE LEVEL OF LOCAL-GOVERNMENT IN CASE OF FLOODS}

Solving the issue of functioning of local selfgovernment in emergency situations remains the design of protection and rescue in emergency situations through its operationalization in the form of the Plan of protection and rescue in emergency situations, more precisely, the part referring to floods. The project approach to the development of the Protection and Rescue Plan in Emergency Situations is the basis of its success. It sufficiently shows that its design is complex and responsible.

Each management process begins with a design that can be defined as the process of setting up future goals, assumptions about the environment in which certain activities need to be implemented, the choice of the direction of the action, the means and the way of achieving the goals — designing includes analyzing the opportunities and possibilities of the system in a changing environment, the total potentials, advantages and disadvantages, alternative directions of development, etc. This design does not include precise and formal short-term and long-term projects, but a long-term strategic orientation of the system, which implies a diagnosis of the security environment, determining the direction of action, the goals to be achieved, the strategy to be chosen for achieving these goals, and decision making through all these phases.

Finally, the project management of emergency situations at the level of local self-government in case of floods should be considered as an essential and integral part of responsible governance. In a variety of decisions, by assessment of risks and chances, in 
conditions of increased uncertainty and rapid changes, apart from perceiving errors and failures, the new uncertain moments cannot be excluded [9].

Planning as a measure of preventing emergency management provides enough time for the system, that is local self-government to consider all possibilities, consider everything, consider the benefits of different procedures, and even check the extent to which they are ready to work. It is easier to perform each of these important tasks in normal times, and it is very difficult and stressful during or in an emergency situation caused by floods [10].

Looking at the context of the Disaster Risk Reduction and Emergency Management Act, the article. 17, it is defined that: "The Plan of Protection and Rescue plans measures and activities for preventing and mitigating the consequences of disasters, strengths and resources of the subjects of the system of disaster risk reduction and emergency management, their organized and coordinated engagement and operation in emergency situations for the purpose of protection and saving people, material and cultural goods and providing basic living conditions" [4]

It is further stated that the Plan contains certain components:

- early warning and readiness (readiness);

- mobilization and activation;

- protection and rescue by type of danger;

- civil protection measures;

- use of forces and subjects of protection and rescue.

The same Law stipulates that the Protection and Rescue Plan is developed on the basis of a risk assessment and adopts at the latest 90 days after the adoption of the risk assessment, and is regularly aligned with changes in the risk assessment.

The plan for protection and rescue of the autonomous province and the plan of protection and rescue of local self-government units shall be adopted by the competent bodies of the autonomous province, i.e. the local self-government unit, upon the approval of the Ministry, upon the proposal of the competent staffs.

The plan for protection and rescue is periodically updated in accordance with the needs and new circumstances, as a whole it is re-created and adopted every third year, and if the circumstances have significantly changed in the past in accordance with the disaster risk assessment.

The protection and rescue plan shall be drafted and issued by all entities that are obliged to make a risk assessment of disasters.

The plan of protection and rescue is applied in both the war and the state of emergency.
The content, manner of drafting and obligations of the entities related to the development of risk assessment of disasters and protection and rescue plans are prescribed by the Government.

The methodology, the manner of preparation and the content of the risk assessment of disasters and the protection and rescue plan shall be prescribed by the Minister of Internal Affairs (hereinafter: the Minister).

Parts of the disaster risk assessment and protection and rescue plan may be marked with the appropriate security level in accordance with law [4].

Referring to the Law and the Regulations relating to the Emergency Response and Rescue Plan, it can be stated that it is comprehensive. However, the key issue remains to what extent the people who need to make such plans are trained, functionally educated and profiled to do so in quality to make operational plans for concrete situation. Therefore, in a particular emergency situation caused by floods, people responsible for emergency situations must be trained to effectively know their roles, to know how to use that equipment, and how to behave.

The importance of planning follows from the four most important aspects:

- contribution to the achievement of the purpose and goals of the work,

- priority in control functions,

- the ubiquity of planning and

- planning efficiency.

Planning logically precedes the execution of all other management functions, because the person in charge of emergency situations must plan and know what kind of organizational relationships and special qualifications are needed, which way leads subordinates and what type of control should be applied, so first it is necessary to plan all others management functions [10].

The problems of planning and management in optimal resource exploitation during the realization of certain projects should be under special attention [10]

Bearing in mind the complexity and specificity of each emergency situation, in the preparation of the Protection and Rescue Plan in emergency situations, regardless of the cause of the emergency situation, the following steps in the development of an effective Plan for protection and rescue in emergency situations should be followed:

Step 1: Create a planning team;

Step 2: Assess the scope of the problem;

Step 3: Make a plan;

Step 4: Check the plan and

Step 5: Update the plan.

The most important processes in emergency management are: creating a concept of organizational and procedural conditions for more efficient flood 
management and management of special structures for responding to emergencies and the response forces in such situations.

The plan of protection and rescue includes all structures relevant to the emergency situation and planned procedures for responding to the emergency flood system. A good plan is short and precise. Creation of the procedures in the form of checklists ensures that they include only important things. The Protection and Rescue Plan covers all points and shows who is responsible for what.

Basically, the Emergency Response Plan contains the following elements:

- assumption of events, goals and purposes;

- allowed activities (procedures);

- forming of special structures (organization);

- forces to respond to an emergency situation;

- defining forces, areas, regions and jurisdictions in response to an emergency situation;

- activities and responsibilities specific to emergency management;

- establishing special procedures for dealing with critical events;

- chain of command (responsibilities) and warnings;

- models of escalation and de-escalation;

- the information inside and outside the system,

- $\quad$ specific measures for restoring normal work;

- post-emergency information;

- creating scenarios based on the plan components;

- evacuation;

- power failure;

- epidemic.

Here are the main elements of the project approach to the development of the Plan that are implemented for each local self-government. It is made up of a group of experts or teams appointed by the head of local self-government and implemented through specific simulation exercises. The Emergency Response Plan must be constantly upgraded and updated [9].

Such a process is simply unmanageable without a project approach. The project approach to the drafting of the Plan for protection and rescue in emergency situations at the level of local self-government represents the bridge between the present and the desired position of the system and the way of managing the emergency situation. Without design, work is left to the case. Designing is an intellectually demanding process because it requires that the direction of action and the basis of the decision on the purpose, knowledge and precise estimations are clearly determined [10].

Finally, the key issues, as a prerequisite for the successful functioning of local self-government in emergency situations in the event of floods, are the persons directly responsible for the development of emergency protection and rescue plans and the functioning in emergency situations. The basic problem in this part is the insufficient number of such persons and the inadequate educational profile. In most local self-governments, persons with their school education and educational profile are inadequate in this business. This results in a superficial approach in the functioning of protection and rescue in emergency situations. The individuals are not educated and are not being trained with professional forms of training for emergency response.

\section{CONCLUSION}

The article explains the emergency situations as a result of sudden events that carry different types of damage with it, endangering people, material goods and the environment. The focus is on the situation in local governments, primarily related to the consequences of floods and their organization for responding to such situations.

A survey conducted within the project "Model of functioning of local self-government in emergency situations (in case of floods), No. 142-451-2675/20181, approved and financed by the Provincial governments in the territory of AP Vojvodina, which are referential to this issue, indicates that there are various problems in the functioning of local selfgovernment in such situations.

This article highlights the most important elements relevant to the development of the project for the preparation of the Emergency Response and Emergency Plan with the aim of successful management of emergency situations in case of floods. The importance of drafting the Protection and Rescue Plan in Emergency Situations is essential for each local self-government and precise definition of the procedures for dealing with the emergency situation caused by floods.

It is very important to point out that the Emergency Response and Emergency Plan is based on defining the procedures that will be used in emergency situations. The project management enables the development of Protection and Rescue Plan that provides its applicability in case of floods.

\section{ACKNOWLEDGEMENT}

The work was created as a result of the project no. 142-451-2675 / 2018-1 from 04. 07. 2018. approved and financed by the Provincial Ministry of Education of AP Vojvodina under the title "Model of functioning of local self-government in emergency situations (in case of floods)", on which we express special gratitude. 


\section{REFERENCES}

[1] D. Kršljanin, and S. Karović, "Sistem odbrane u vanrednim situacijama", Vojno delo 4/2015, Beograd, 2015, pp. 142-171.

[2] D. Đorđević, and S. Karović, "Mehanizmi prevencije za uspešno funkcionisanje sistema odbrane u vanrednim situacijama", Vojno delo 2/2017, Beograd, 2017, pp. 90-203.

[3] Š. Bajrami, S. Karović, and G. Radić, "Upotreba Rečne flotile u pružanju pomoći civilnim vlastima u slučaju velikih poplava", Vojno delo 7/2016, Beograd, 2016, pp. 245-268.

[4] Zakon o smanjenju rizika od katastrofa i upravljanju vanrednim situacijama, "Sl. glasnik RS", br. 87/2018, Beograd, 2018.

[5] S. Savić, and M. Stanković, "Teorija sistema i rizika", Akademska misao, Beograd, 2012.
[6] D. Mlađan, "Bezbednost u vanrednim situacijama", Kriminalističko-policijska kademija Beograd, 2015, p. 70.

[7] Nacionalna strategiju zaštite i spasavanja u vanrednim situacijama, "Službenom glasniku RS", br. 86/2011 od 18.11.2011. godine.

[8] S. Karović, "Krizni menadžment", Medija centar "Odbrana", Beograd, 2014.

[9] S. Karović, H. Radončić, and G. Radovanović, "Crisis Project - Basis of Crisis Resolution", Serbian Project Management Journal, Volume 5, Issue 1, Beograd, 2015, pp. 67-75.

[10] S. Karović, and M. Pušara, „Projektno-operativno planiranje i upravljanje procesa odlučivanja u vojnom menadžmentu", SYMORG, Beograd, 2008. 